\title{
Clinico-Pathological Study of Sarcomatous Neoplasms- Five Year Data of a Regional Cancer Center
}

\author{
Authors \\ Dr Sanjukta Padhi ${ }^{1}$, Dr Bikash Ranjan Mahapatra ${ }^{2}$, Dr Papuji Meher ${ }^{3}$, \\ Dr Bijayalaxmi Sahoo ${ }^{4}$, Dr Sagarika Samantray ${ }^{5}$ \\ ${ }^{1}$ Associate Professor, Department of Radiotherapy, AH Regional cancer Center, Cuttack \\ ${ }^{2,3,4}$ Junior Resident, Department of Radiotherapy, AH Regional cancer Center, Cuttack \\ ${ }^{5}$ Associate Professor, Department of Pathology, AH Regional cancer Center, Cuttack \\ Corresponding Author \\ Dr Sanjukta Padhi \\ Pithapur, Cuttack, Odisha \\ Email:drsanjuktapadhi@gmail.com
}

\begin{abstract}
Introduction- Sarcomatous tumors are one of the rarest malignancies of all. They are either mostly of osseous or extraosseous origin. These malignancies have very aggressive behaviour and poor outcomes.

Aims- To study age, sex, site, histological distributions among the study population.

Methods: Retrospective study of 130 patients conducted from institutional medical records from 2013 to 2017. Results- Among 130 patients there was slight male predominance. Age groups 40-59yrs followed by age less than 20 yrs were commonly encountered. Lower extremity was the most common anatomical site and spindle cell sarcoma was the most common histological subtype found.

Conclusion- Though rare, sarcomas are widely distributed occurring at various anatomical sites. Various types of histological patterns are seen. Early diagnosis and aggressive treatment is demanded in order to achieve a remarkable survival and control.
\end{abstract}

Key words- Sarcoma, Soft tissue sarcoma.

\section{INTRODUCTION}

Sarcomatous neoplasms include the osseous and extraooseous tumors that are mostly of mesenchymal origin. They represent $1 \%$ of all malignant tumors ${ }^{[1]}$

Sarcomas can start anywhere in the body. Soft tissue sarcomas often form in the body's muscles, joints, fat, nerves, deep skin tissues, and blood vessels. There are more than 30 types of sarcoma, making each extremely rare entity. Depending upon types of cancer cells sarcomas are classified into groups. They usually are named after the type of tissue origin ${ }^{[2]}$ Sarcomas, although relatively rare, are quite deadly, especially soft tissue sarcomas. The primary reason being the delayed diagnosis and advanced disease, or metastasis at presentation [3]. Early diagnosis is often missed due to lack of distinct symptoms.

\section{AIMS AND OBJECTIVES}

The purpose of this study is to perform a analysis on epidemiological parameters of sarcomas according to age, gender, sites of origin and histological types. 


\section{MATERIALS \& METHODS}

A total of 130 cases were studied retrospectively. All data were retrieved from institutional medical records. The data were compiled analysed using MS excel. The study period was from 2013 to 2017.

\section{RESULTS}

A total of 130 cases were studied. Among them 67 cases i.e., $51 \%$ were males and rest 63 cases were females.[Table-1] As per age group distribution most cases $31 \%$ were from 40-59 yrs followed by pediatric age groups $(<20 \mathrm{yrs})$ of $25 \%$.[Table-2]. In context to anatomical sites majority of tumors arise from extremities comprising of 84 cases of which $65 \%$ were in lower extremity. Lower extremity was the major site among all anatomical sites. Following extremity pelvis was next most common site followed by abdomen.[Table-3] Spindle cell sarcoma was the most common histological subtypes that comprise of 53 cases (40\%) followed by pleomorphic sarcomas of almost $18 \%$. Osteogenic sarcoma was next common histology encountered following the pleomorphic sarcoma which was most commonly seen in patients $<20 \mathrm{yrs}$ of age. [Table-4] In both the sexes spindle cell sarcoma was the most common histological subtype found. Among all the cases of spindle cell sarcoma the lower extremity was the most common site and the most common age group found was 40-59yrs. Other histology like angiosarcoma, chondrosarcoma, liposarcoma, fibromyxoid variety, neurofibrosarcomas were also seen. All the seven cases of Ewings sarcoma were seen in age <20yrs. Almost all the leiomyosarcomas were from the uterine primary.

Table-1: Showing sex distribution

\begin{tabular}{lc}
\hline GENDER & NUMBER OF CASES \\
\hline MALE & 67 \\
FEMALE & 63 \\
\hline
\end{tabular}

Table-2: Showing distribution as per age groups

\begin{tabular}{cc}
\hline AGE GROUPS(in yrs) & NUMBER OF CASES \\
\hline$<20$ & 32 \\
$20-39$ & 30 \\
$40-59$ & 40 \\
$60-79$ & 26 \\
$>80$ & 02 \\
\hline
\end{tabular}

Table-3: Distribution according to sites

\begin{tabular}{lc}
\hline ANATOMICAL SITES & NUMBER OF CASES \\
\hline LOWER EXTREMITY & 70 \\
UPPER EXTREMITY & 14 \\
PELVIS & 13 \\
ABDOMEN & 10 \\
(INCLUDING & \\
RETROPERITONEUM) & \\
THORAX & 10 \\
HEAD \& NECK & 04 \\
\hline
\end{tabular}

Table-4: Showing Histological types

\begin{tabular}{lc}
\hline HISTOLOGY & NUMBER OF CASES \\
\hline SPINDLE CELL SARCOMA & 53 \\
PLEOMORPHIC SARCOMA & 24 \\
OSTEOSARCOMA & 17 \\
EWING'S SARCOMA & 07 \\
LEIOMYOSARCOMA & 06 \\
OTHERS & 23 \\
\hline
\end{tabular}

Table-5: Showing histological types in males

\begin{tabular}{lc}
\hline HISTOLOGY & NUMBER OF CASES \\
\hline SPINDLE CELL SARCOMA & 25 \\
PLEOMORPHIC & 12 \\
OSTEOSARCOMA & 11 \\
OTHERS & 19 \\
\hline
\end{tabular}

Table-6: Showing histological types in females

\begin{tabular}{lc}
\hline HISTOLOGY & NUMBER OF CASES \\
\hline SPINDLE CELL SARCOMA & 28 \\
PLEOMORPHIC & 10 \\
OSTEOSARCOMA & 08 \\
LEIOMYOSARCOMA & 05 \\
OTHERS & 12 \\
\hline
\end{tabular}

\section{DISCUSSION}

Age is an important determinant of sarcoma occurrence. Based on current statistics provided by the NCHS and SEER, from 2004-2008, the mean age at diagnosis for soft tissue sarcomas was $58^{[4] \text {. }}$ In our study the most common age group to develop sarcoma was 40-59yrs. Young age group (20-39yrs) were comparative less incidence of sarcomas than age more than 40yrs.

In SEER data (1973-2008), we observed that soft tissue sarcomas currently occur much more frequently than malignant bone tumours. In 2008, soft tissue sarcomas accounted for nearly $87 \%$ of all sarcomas diagnosed, while the remaining $13 \%$ of the diagnoses were malignant bone tumors ${ }^{[4]}$. In our study we found majority of cases were soft tissue 
sarcoma $81 \%$ and the bone tumours constitute $19 \%$ among the all bone tumours osteosarcoma was the most common bone tumour encountered which is corroborative with SEER data (1973-2008).

International comparison of gender predilection for STS reveals diverse findings. Higher incidence of STS in females, as found in Austria, is reported for Switzerland to ${ }^{[5]}$. In the United States, the two studies of Ross et al. ${ }^{[6]}$ and Toro et al. ${ }^{[7]}$ present different male-to-female ratios, even though both studies have comprised their dataset from the SEER program. In our study we found its slightly male predominance. Thus, with this inconsistency in the results from the different studies, no clear tendency in the gender predilection can be stated, and drawing conclusions concerning the causation of these findings seems unreasonable.

The approximate distribution of STS sites at presentation is extremity, 60\% (lower extremity, $45 \%$, upper extremity, $15 \%$ ); trunk, $15 \%$ to $20 \%$; retroperitoneum, $10 \%$ to $15 \%$; and head and neck, $8 \% .{ }^{[8]}$ In our study we found the lower extremity is the most common site followed by upper extremity .

\section{CONCLUSION}

The knowledge of STS is scattered and incomplete and studies are hampered by the rarity and heterogenous nature of the disease. The available literature and research on sarcoma has shown that these rare diseases are difficult to study. Various types of soft tissue sarcoma are found which affects various parts of the body and the names of the sarcoma are given according to the affected parts. At an early stage if the symptoms are diagnosed then it can be cured. The percentage for the cure in advanced disease is very low. Understanding of clinicopathological correlation, molecular biology and aggressive tumor behaviour are of utmost importance to achive a good cure rate and control.

\section{REFERRENCES}

1. Fletcher CD, Krishnan Unni K, Mertens F (2002). Pathology and genetics of tumours of soft tissue and bone. In Kleihues PM, Sobin LH (eds), World Health Organization Classification of Tumours, 4th edition. Lyon, France: IARC Press 2002; 10-6, 1204. Gladdy RA, Qin

2. Singer S (1999). New diagnostic modalities in soft tissue sarcoma. Semin Surg Oncol 17 (1): 11-22.

3. A Snapshot of Sarcoma. National Cancer Institute. Sept 2010. http://www.cancer.gov/aboutnci/servingpeop le/cancer-statistics/snapshots

4. Surveillance, Epidemiology, and End Results (SEER) Program (www.seer.cancer.gov) SEER*Stat Database: Incidence - SEER 9 Regs Research Data, Nov 2010 Sub (1973-2008) $<$ Katrina/Rita Population Adjustment $>$ Linked To County Attributes - Total U.S., 1969-2009 Counties, National Cancer Institute, DCCPS, Surveillance Research Program, Cancer Statistics Branch, released April 2011, based on the November 2010 submission.

5. Levi F, La Vecchia C, Randimbison L, Te VC. Descriptive epidemiology of soft tissue sarcomas in Vaud, Switzerland. Eur $\mathbf{J}$ Cancer 1999; 35: 1711-1716.

6. Ross JA, Severson RK, Davis S, Brooks JJ. Trends in the incidence of soft tissue sarcomas in the United States from 1973 through 1987. Cancer 1993; 72:486-490.

7. Toro JR, Travis LB, Wu HJ et al. Incidence patterns of soft tissue sarcomas, regardless of primary site, in the surveillance, epidemiology and end results program, 1978-2001: an analysis of 26,758 cases. Int J Cancer 2006; 119:2922-2930.

8. Lawrence W Jr, Donegan WL, Natarajan N, et al. Adult soft tissue sarcomas. A pattern of care survey of the American College of Surgeons. Ann Surg 1987;205(4):349-359. 